http://journal.uinsgd.ac.id/index.php/biodjati

\title{
GENETIC RELATIONSHIP OF THE TRANSGENIC AND NON-TRANSGENIC MUTIARA CATFISH WITH THEIR HYBRIDS SANGKURIANG CATFISH
}

\author{
Iskarimah Yolanisa*1, Ibnu Dwi Buwono², Yuniar Mulyani³, Iskandar ${ }^{4}$
}

Received : May 27, 2019

Accepted : September 26, 2019

DOI: 10.15575/biodjati.v4i2.4741

1,2,3,4Faculty of Fishery and Marine Science, Universitas Padjadjaran Jl. Raya Bandung Sumedang, Kec. Jatinangor, Sumedang districts, West Java, Indonesia 45363

e-mail:

'iyolanisa@gmail.com

*2ibnu.dwi.buwono@unpad.ac.id

3yuniarmulyani@gmail.com

${ }^{4}$ nday iskandar@yahoo.co.id

*Corresponding author

\begin{abstract}
The Transgenic "Mutiara" catfish is a fast growth fish containing Clarias gariepinus Growth Hormone (CgGH). Crossing between male transgenic Mutiara catfish and the non-transgenic one produced expecting $F 1$ and $F 2$ hybrids carrying superiority inheritance from the transgenic parent. This study analyzed genetic relationship using RAPD among the parent, hybrids and "Sangkuriang" catfish as additional material. Genomic DNA extraction and purification from catfish caudal fin tissue sample was performed using Wizard $\mathbb{R}$ Genomic DNA Purification kit (Promega). The selected primers used for the amplicons in the PCR process were OPA-03 and OPA-16. In the analysis phase, DNA fragments in the form of monomorphic and polymorphic fragments were then processed using the NTSYSpc-2.02 (Numerical Taxonomy and Multivariate Analysis System) program and produced a phenogram. The results showed that only OPA-03 (5'-AGTCAGCCAC-3') primer enabled to determine DNA polymorphism among catfish samples. The closest genetic similarity index originates from the female broodstock of Non-Transgenic Mutiara catfish (P) (93\%), while the furthest originates from the male broodstock of Mutiara Transgenic catfish (P) (51\%) with F1 dan F2.
\end{abstract}

Keywords: genetic relationship, Mutiara catfish, polymorphism, Sangkuriang catfish, transgenic

\section{Citation}

Yolanisa, I., Buwono, I. D., Mulyani, Y. \& Iskandar. (2019). Genetic Relationship of the Transgenic and Non-transgenic Mutiara Catfish with Their Hybrid Sangkuriang Catfish. Jurnal Biodjati, $4(2), 204-213$

\section{INTRODUCTION}

Freshwater aquaculture activities in Indonesia especially catfish farming are promising enterprise because their cultured is relatively easy and local market consumption demand is still high (Muhammad \& Andriyanto, 2013). Short maintenance age (3-4 months) for the needs of "pecel lele" (Indonesian deep fried catfish) makes catfish a profitable business. This business opportunity encourages fish farmers to apply catfish culture intensively, with the use of high stocking densities and routine artificial feeding. This condition causes the demand for high catfish seeds and encourages the fish farmer to increase the frequency of broodstock spawning to fill the continued long-term demand.

Frequent use of the same broodstock in spawning by fish farmers (breeder) on freshwater aquaculture activities might cause the degradation of fish phenotype due to a high 


\section{JURNAL BIDDJATI}

http://journal.uinsgd.ac.id/index.php/biodjati

rate of inbreeding. It leads to a decrease in superior character of the broodstock to offspring (Yousefian \& Nejati, 2008; Chattopadhyay, 2017). Genetic improvement efforts that can be done is selective breeding (Iswanto et al., 2015). To date, catfish selective breeding programs have been carried out by the Fish Breeding Research Center (BPPI) Sukamandi which produces "Mutiara" catfish and has been officially disseminated to the public based on Decree of the Minister of Maritime Affairs and Fisheries Republic of Indonesia No.77/KEPMEN-KP/2015 (BPPI, 2014).

Genetic quality improvement of catfish can also be performed using hybridization and transgenesis technology. On hybridization, superior features within a few generations are not always inherited due to the effect of temporary dominance in the hybrid fish (Liu, 2007). While on transgenesis fish, the stability of inheritance from excellent character (growth) is displayed on the F1 and F2 offspring, showing growth gene construct integrated into the fish's genome (Alimuddin et al., 2003; Rasal et al., 2016). Transgenesis application in $\mathrm{Mu}-$ tiara catfish using $\mathrm{CgGH}$ (Clarias gariepinus Growth Hormone), gene transfer (Buwono et al., 2016), and PhGH (Pangasius hypophthalmus Growth Hormone) gene transfer in African catfish (Dewi et al., 2013) were able to increase the catfish size two times larger than normal catfish.

Strain descent transgenic Mutiara catfish has been proved to have $\mathrm{CgGH}$, while the genetic relationship among transgenic and non-transgenic Mutiara catfish broodstock (P) with first (F1) and second (F2) offspring hybrids of transgenic and non-transgenic Mutiara catfish need to be examined to determine stabilization of a decrease in the superior properties. Analysis of RAPD (Random Amplified Polymorphic DNA) were represented by monomorphic and polymorphic fragments that illustrate the genetic relationship of broodstock to each offspring ( $\mathrm{F}=$ filial) (Dunham, 2004; El-Hawary et al., 2018). In this study, genetic analysis was carried out on the transgenic and non-transgenic Mutiara catfish broodstock (P) with F1, F2 offspring hybrids and Sangkuriang catfish as an effort to prevent inbreeding in the breeding program.

\section{MATERIALS AND METHODS}

Two-years-old transgenic and non-transgenic Mutiara catfish broodstock $(\mathrm{P})$, oneyear-old F1 offspring, one-month-old F2 offspring and one-year-old Sangkuriang catfish were used as research samples. Fish genomic DNA was extracted using the Wizard ${ }^{\circledR}$ Genomic DNA Purification kit (Promega). The genomic DNA extraction was carried out using catfish caudal fin tissue, hence DNA can be obtained without injure or kill the fish. The presence and quality of genomic DNA were determined by doing DNA quantitative testing with the spectrophotometer through calculating the ratio of $\AA 260 / \AA 280 \mathrm{~nm}$ wherein the UV light wavelength of $260 \mathrm{~nm}$ is absorbed by the double-helix DNA, while long-wave UV light at $280 \mathrm{~nm}$ is absorbed by the proteins or phenols contaminant, thus the measurement of the purity in the genomic DNA is known (Fatchiyah et al., 2011).

The process of amplification using two kinds of arbitrary size 10 nucleotide primers with 10 base pairs manufactured by Operon Technology (Alameda, California), namely OPA-03 and OPA-16 (Table 1). Two primers selected from the reference from several studies, OPA-03 primer used by Danish et al. (2012) in Clarias batracus; Diani (2013) in local, Dumbo and Sangkuriang catfish; and Buwono et al. (2018) in F1 offspring hybrids of transgenic and non-transgenic Mutiara catfish and Sangkuriang catfish, while OPA-16 


\section{JURNAL BIDDJATI}

http://journal.uinsgd.ac.id/index.php/biodjati

primer used by Beheary et al. (2015) in Clarias gariepinus and Buwono et al. (2018) in F1 offspring hybrids of transgenic and non-transgenic Mutiara catfish and Sangkuriang catfish. Both primers (OPA-03 and OPA-16) considered as a selected primer that has a complementary sequence with the transgenic and non-transgenic Mutiara catfish broodstock (P) with F1, F2 offspring hybrids and Sangkuriang catfish sequence.

Table 1. RAPD Primer List With Sequence Bases

\begin{tabular}{cc}
\hline Primer & Sequences \\
\hline OPA-03 & AGT CAG CCAC \\
OPA-16 & AGC CAG CGAA \\
\hline
\end{tabular}

Exploratory method and qualitative descriptive analysis were used in this study. PCR were performed in $25 \mu 1$ reaction volume containing GoTaq fast $2 \mathrm{G} \circledast$ master mix 12.5 $\mu 1$, Nuclease-Free Water (NFW) $9.5 \mu 1,1.0$ $\mu 1$ RAPD Primer (OPA-03 and OPA-16), and template DNA $2.0 \mu$ l. The DNA qualitative test performed by agarose gel electrophoresis (Williams et al., 1990). The electrophoresis was carried out at 60 volts for 35 min using $1 \%$ agarose gel and TBE buffer. The gel was removed and stained with $5 \mu 1 \mathrm{EtBr}$ (Ethidium Bromide) solution for 25 minutes and rinsed with $100 \mathrm{ml}$ distilled water for 8 minutes. Reaction mixtures were amplified in Sensoquest Labcycler, programmed for 45 cycles with a final extension step at $72^{\circ} \mathrm{C}$ for 5 minutes. Each cycle consists of denaturation at $94{ }^{\circ} \mathrm{C}$ for 1 minunte, annealing at $36^{\circ} \mathrm{C}$ for $1 \mathrm{~min}$ ute and extension at $72^{\circ} \mathrm{C}$ for 2 minutes. PCR reaction product was separated by electrophoresis in 1\% agarose using TBE buffer for 85 min at 55 volts.

The results of DNA amplification using RAPD primers were interpreted with the NTSYSpc-2.02 (Numerical Taxonomy and Multivariate Analysis System) program to determine genetic relationships among samples.
This program will display genetic similarities. The genetic distance was calculated using a method developed by Nei \& Li (1979) that the GD $($ genetic distance $)=1$ - GS $($ genetic similarity).

\section{RESULTS AND DISCUSSION}

\section{Genomic DNA Extraction}

The degree of purity of DNA has a ratio value of 1.8 to 2.0 (Barbas et al., 2007). If the value of the ratio is less than 1.8 then there is still protein or phenol contamination in the solution (Tenriulo et al., 2001), while the greater ratio more than 2.0 was indicated DNA contamination of RNA (Khosravinia et al, 2007). According to the results (Table 2 ), all samples were in range ratio expressing the purity of tested DNA. Furthermore the genomic DNA tested by electrophoresis and results test shown in Figure 1.

The electrophoresis genome results showed smear visualization. Therefore, DNA quality measurement indicated eligible and qualified to be samples templates for DNA amplification. 
Jurnal Biodjati 4(2):204-213, November 2019

\section{JURNAL BIDDJATI}

http://journal.uinsgd.ac.id/index.php/biodjati

Table 2. Catfish Genome DNA Purity Test Ratio Value

\begin{tabular}{|c|c|c|c|c|c|}
\hline No. & Sample & Abs 260 & Abs 280 & Ratio & Consentration $(\mathrm{ng} / \mu \mathrm{l})$ \\
\hline 1 & $\begin{array}{l}\text { (P) Male Transgenic Mutiara Catfish } \\
\text { ( } \ \text { MTG) }\end{array}$ & 0.112 & 0.061 & 1.836 & 280 \\
\hline 2 & $\begin{array}{l}\text { (P) Female Non Transgenic Mutiara } \\
\text { Catfish (q MNT) }\end{array}$ & 0.163 & 0.086 & 1.895 & 407.5 \\
\hline 3 & $\begin{array}{l}\text { (P) Male Non Transgenic Mutiara } \\
\text { Catfish }\left(\delta^{\lambda} \mathrm{MNT}\right)\end{array}$ & 0.177 & 0.097 & 1.824 & 442.5 \\
\hline 4 & (F1) MTG $><$ MNT Male Catfish & 0.258 & 0.143 & 1.804 & 645 \\
\hline 5 & (F1) MNT $><$ MNT Female Catfish & 0.129 & 0.07 & 1.842 & 322.5 \\
\hline 6 & $\begin{array}{l}\text { (F2) MTG_MNT }><\text { MNT_MNT } \\
\text { Catfish }\end{array}$ & 0.13 & 0.068 & 1.911 & 325 \\
\hline 7 & Sangkuriang Catfish (control) & 0.216 & 0.111 & 1.945 & 540 \\
\hline
\end{tabular}

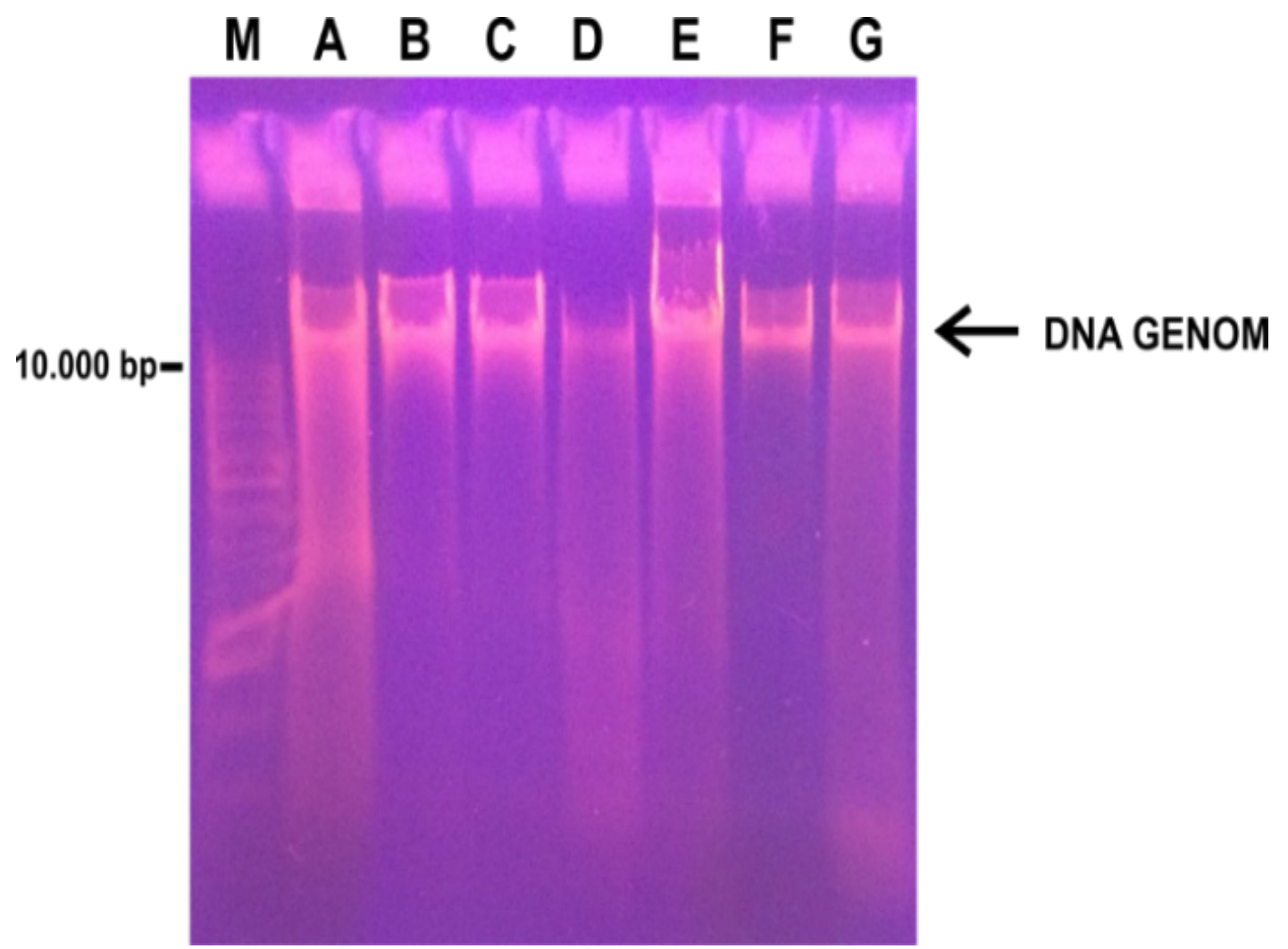

Figure 1. Catfish Genomic DNA Electrophoresis Results

$\mathrm{A}=(\mathrm{P})$ Male Transgenic Mutiara Catfish ( $\left.{ }^{\Uparrow} \mathrm{MTG}\right) ; \mathrm{B}=(\mathrm{P})$ Female Non Transgenic Mutiara Catfish $(\uparrow \mathrm{MNT}) ; \mathrm{C}=(\mathrm{P})$ Male Non Transgenic Mutiara Catfish $\left({ }^{\Uparrow} \mathrm{MNT}\right) ; \mathrm{D}=(\mathrm{F} 1) \mathrm{MTG}><\mathrm{MNT}$ Male Catfish; E $=($ F1) MNT $><$ MNT Female Catfish; F $=$ (F2) MTG_MNT $><$ MNT_MNT Catfish; G= Sangkuriang Catfish (control) 


\section{JURNAL BIDDJATI}

http://journal.uinsgd.ac.id/index.php/biodjati

\section{Polymorphisms and Heterozygosity}

Electropherogram results from two PCR primers showed OPA-03 primer was the most complementary primer sequences with catfish samples sequences than OPA-16 primer (Figure 2). Annealing temperature precision is factor that affect the success of primer complementary with a DNA sequence in the PCR amplification process thus DNA fragments appear (Zulfahmi, 2013). In OPA-16, primer

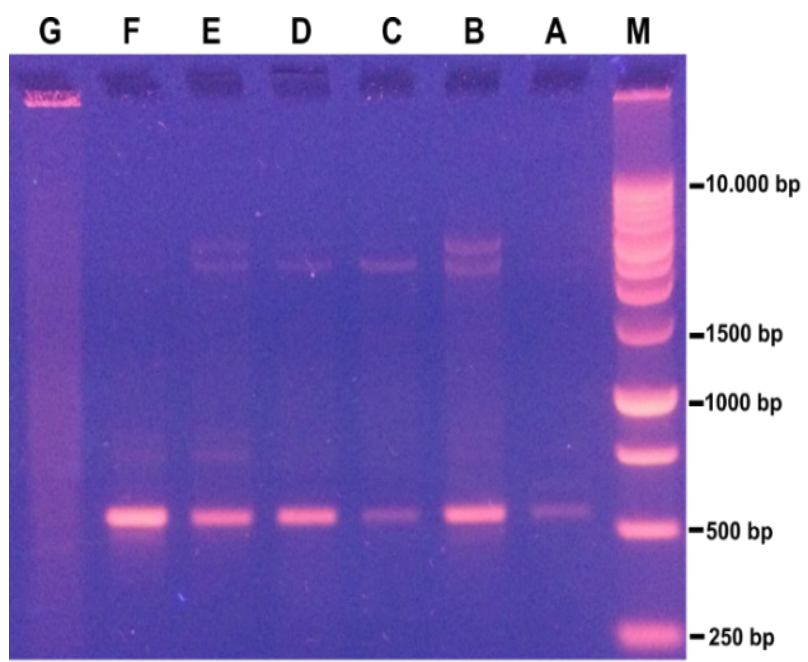

(a) all samples were copied but only produced one line of monomorphic fragments, which indicates all samples closely related. While a number of polymorphic fragments detected by OPA- 03 , this provides a basis to determine genetic variations among samples. Genetic variations (polymorphisms) will serve as a reference point in the management of sustainable aquaculture (Danish et al., 2012).

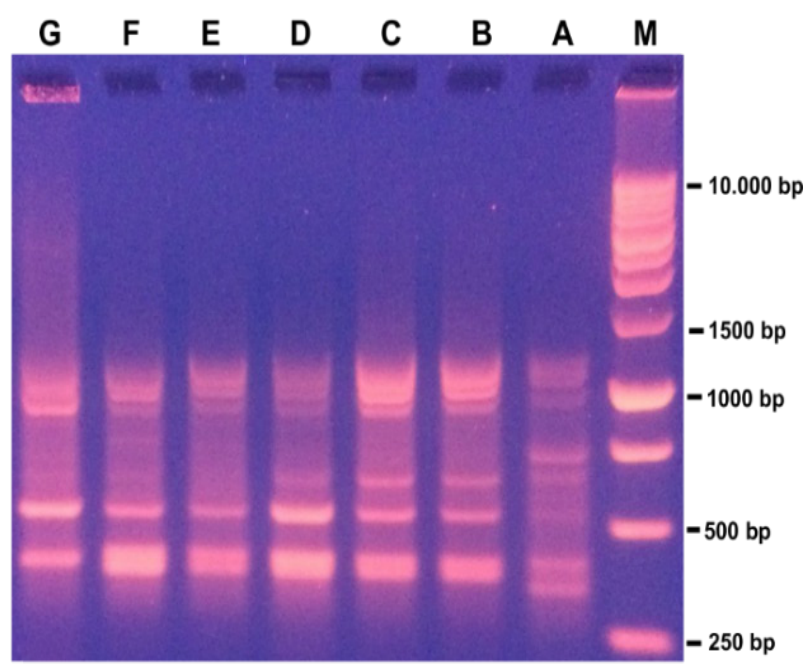

(b)

Figure 2. a) DNA Amplification Result using OPA-16 Primer; b) DNA Amplification Result using OPA-03 Primer

Monomorphic and polymorphic fragments sample using OPA-03 spread to the seven samples (Table 3). The monomorphic fragment is a DNA fragment found in all of the samples at the same size, while polymorphic fragments detected at a specific size and do not recover in other samples. The OPA - 03 primers produced 55 DNA fragments at 342 $1249 \mathrm{bp}$, which 6 of them were polymorphic. Highly reproducible fragment in size range of 200-150 bp generally found in fish (Liu et al., 1999). Danish et al. (2012) also reported OPA-03 primers produced 23 fragments appeared at 240-1360 bp on Clarias bathracus DNA amplification. The presence of polymorphic fragments exhibited a genetic variation among samples that plays an essential role in improving the fish fitness (survival) so it can adapt to the changes in environmental conditions (Dunham, 2004).

The RAPD-PCR fragment results indicated a particular gene linkage as well as a distinct phenotype expression (FAO, 2001; Liu \& Cordes, 2004) that expressed in the Male Transgenic Mutiara Catfish (P) and (F2) offspring hybrids Catfish with 5 and 1 polymorphic fragment respectively (Table 3). RAPD as dominant trait produced homozygotes as much as heterozygotes allele while the heterozygotes generated the polymorphic alleles (Liu, 2007). Buwono et al. (2016) reported transgenic Mutiara catfish has success- 


\section{JURNAL BIDDJATI}

http://journal.uinsgd.ac.id/index.php/biodjati

fully inserted by $\mathrm{CgGH}$ that constructed from two GH gene derived from the fish own body (endogenous) and GH from outside the body (exogenous) thus effects of transgenic catfish revealed polymorphisms.

The polymorphisms found in the transgenic Mutiara catfish (samples A and F) more than non-transgenic Mutiara catfish (samples $\mathrm{B}, \mathrm{C}, \mathrm{E}$ and $\mathrm{G}$ ) that tend to produce monomorphic fragments. Buwono et al. (2018) reported non-transgenic Mutiara catfish and Sangkuriang catfish have a lack of diversity (monomorphism), while in this study (Table 3 ) the monomorphic fragments were generated in all samples on 396 bp, 523 bp and 1035 bp (indicated by parallel fragments). The presence of monomorphic fragments on all samples implies a high level of similarity among samples (Dunham, 2004). Four African catfish strains such as Dumbo, Sangkuriang, Egypt and Paiton catfish were crossed and became the former base population of Mutiara catfish (BPPI, 2014). It explained that the seven samples of this study are descendants of African catfish thus have a kinship relationship.

Table 3. Polymorphic and monomorphic fragments Catfish from OPA-03 Primer Test

\begin{tabular}{|c|c|c|c|c|c|c|c|}
\hline $\begin{array}{l}\text { Distance Fragments of } \\
\text { the wells (bp) }\end{array}$ & $\mathrm{A}$ & $\mathrm{B}$ & $\mathrm{C}$ & $\mathrm{D}$ & $\mathrm{E}$ & $\mathrm{F}$ & G \\
\hline 1249 & $--^{*}$ & & & & & & \\
\hline 1173 & $--^{*}$ & & & & & & \\
\hline 1101 & -- & -- & & -- & -- & & \\
\hline 1035 & $--^{\wedge}$ & $--^{\wedge}$ & $--\wedge$ & $--^{\wedge}$ & $--^{\wedge}$ & $--^{\wedge}$ & $--^{\wedge}$ \\
\hline 986 & -- & & -- & & & -- & \\
\hline 926 & & -- & -- & -- & -- & -- & -- \\
\hline 784 & & & & & & --* & \\
\hline 743 & --* & & & & & & \\
\hline 636 & -- & -- & -- & -- & & -- & -- \\
\hline 580 & $--*$ & & & & & & \\
\hline 523 & $--^{\wedge}$ & $--^{\wedge}$ & $--^{\wedge}$ & $--^{\wedge}$ & $--^{\wedge}$ & $--^{\wedge}$ & $--^{\wedge}$ \\
\hline 416 & & & & -- & -- & -- & \\
\hline 396 & $--^{\wedge}$ & $--^{\wedge}$ & $-^{-} \wedge$ & $--^{\wedge}$ & $--^{\wedge}$ & $--^{\wedge}$ & $--^{\wedge}$ \\
\hline 377 & & -- & -- & -- & -- & -- & -- \\
\hline 342 & --* & & & & & & \\
\hline
\end{tabular}

$--^{\wedge}=$ monomorphic fragment; --* = polymorphic fragment

$\mathrm{A}=(\mathrm{P})$ Male Transgenic Mutiara Catfish ( $\left.{ }^{\lambda} \mathrm{MTG}\right) ; \mathrm{B}=(\mathrm{P})$ Female Non Transgenic Mutiara Catfish $(\mathrm{Q}$ MNT); C =

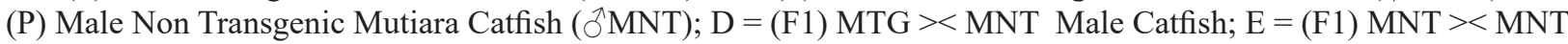
Female Catfish; F = (F2) MTG_MNT $><$ MNT_MNT Catfish; G = Sangkuriang Catfish (control) 


\section{JURNAL BIDDJATI}

http://journal.uinsgd.ac.id/index.php/biodjati

\section{Genetic Relationship Analysis}

The results of the RAPD analysis using the OPA-03 of the seven isolates genomic DNA (Figure 3) divided into two main clusters to produce the dendrogram of genetic relationship (Mahaputro et al., 2012; Adolfsson, et al., 2018).

Cluster I consisting of male transgenic Mutiara catfish (P) (sample A) that has 51\% genetic similarity with other 6 samples. Based on the Nei \& Li (1979) method, genetic distance (=GD) value estimated by genetic similarity relatively high $49 \%$. This excessive value indicating high-level genetic variation due to sample A is the broodstock that not descended from reproduction but emanates from Mutiara catfish transferred growth hormone (GH) gene of Dumbo catfish. This maybe the reason for genetic variations (polymorphisms) compared with non-transgenic Mutiara catfish and the descendants.

Cluster II involving sample B, sample C, sample D (offspring of sample A and B), sample E (offspring of sample B and C), sample $F$ (offspring of sample D and E), and samples $\mathrm{G}$ divided into three subcluster. Subcluster I involves Sangkuriang catfish (sample G) with female non-transgenic Mutiara catfish (P) (sample B), non-transgenic Mutiara catfish (P) (sample C), F1 hybrid offspring of male transgenic Mutiara catfish (P) with female non-transgenic Mutiara catfish broodstock (sample D), F1 hybrid offspring of male non-transgenic Mutiara catfish $(\mathrm{P})$ with female non-transgenic Mutiara catfish broodstock (sample E), and F2 hybrid offspring of F1 transgenic and non-transgenic Mutiara catfish (sample F). Subcluster II involves 2 samples of fish (sample C and F), while subcluster III involves 3 samples of fish (sample B, D and E).

Genetic distance among samples in subcluster I (24\%) relatively lower compared to cluster I (similarity 76\%). The fact that Sangkuriang catfish which was one of the founders of Mutiara catfish history formation is a hybrid backcross result, made the samples (F1 and F2 offspring hybrids of Mutiara catfish) separated apart genetically as revealed by genetic distance analysis. Liu (2007) reported that superior features are not always inherited in hybrid offspring strains or not permanent. Moreover, subcluster II and subcluster III exhibited GS of $78 \%$ while the GD apart from each other by $22 \%$, indicating low-level genetic variation compared with subcluster I. This implies more homogenity among five genetic fish samples (sample B, D, E, C and F). However, subcluster II that consists of sample $\mathrm{C}$ and sample $\mathrm{F}$, has $87 \%$ GS with $13 \%$ GD which affirms the genetic distance between these fish higher when compared with subcluster III. One polymorphic fragment that appears on sample F (Table 3) indicates that genetic variation detected, contribution of alleles from the male transgenic Mutiara catfish (P) estimated as a cause of the polymorphism. Buwono et al. (2018) reported polymorphic fragments appeared on the F1 hybrid offspring transgenic and non-transgenic Mutiara catfish.

The lowest GD (7-11\%) were found in subcluster III involving sample B, sample D (offspring of sample A and B), and sample E (offspring of sample B and C) while their GS values range from $89-93 \%$. The genetic similarity approaching $100 \%$ showed a close genetic affinity (Muharam et al., 2012). It confirmed that F1 hybrid offspring of female non-transgenic Mutiara catfish (P) (sample B) crossed with male transgenic Mutiara catfish (P) (sample A) or male non-transgenic Mutiara catfish $(\mathrm{P})$ (sample $\mathrm{C}$ ) have predominance inheritance from female broodstock (sample B), thus genetic similarity between female broodstock and F1 is very close. Cheng et al. (2015) reported F1 hybrid offspring of 


\section{JURNAL BIDDJATI}

http://journal.uinsgd.ac.id/index.php/biodjati

Epinephelus fuscoguttatus (female) (P) $><$ Epinephelus lanceolatus (male) (P) had inherited the mitochondrial DNA (mtDNA) from maternal parent or closely related with Epinephelus fuscoguttatus. Furthermore, Permana et al. (2009) affirmed that the contribution of mtDNA can be inherited only from the mother (maternal inheritance).

The genetic similarity level described by genetic distance and similarity index of individual members of the population (Muharam et al., 2012; Arifin et al., 2017). The high-level of similarity index indicated low-level of genetic variation and generated to inbreeding among a samples (Sofro, 1994). Mating between non-transgenic Mutiara catfish broodstock in the same population should be avoided due to high closely related potential. The closest genetic similarity index of 93\% originates from the female broodstock of non-transgenic Mutiara catfish (P) (sample B) and (F1) MTG $><$ MNT Male Catfish (sample D) had inbreeding potential. While the farthest genetic similarity index of $51 \%$ originates from the male broodstock of male transgenic Mutiara catfish (P) (sample A) with female F1 and F2. Offspring hybrids mating are recommended for producing catfish offspring with better genetic quality. In conclusion, male transgenic Mutiara catfish $(\mathrm{P})$ are distinctive species based on the total number of polymorphic fragments thus increase genetic variation within population.

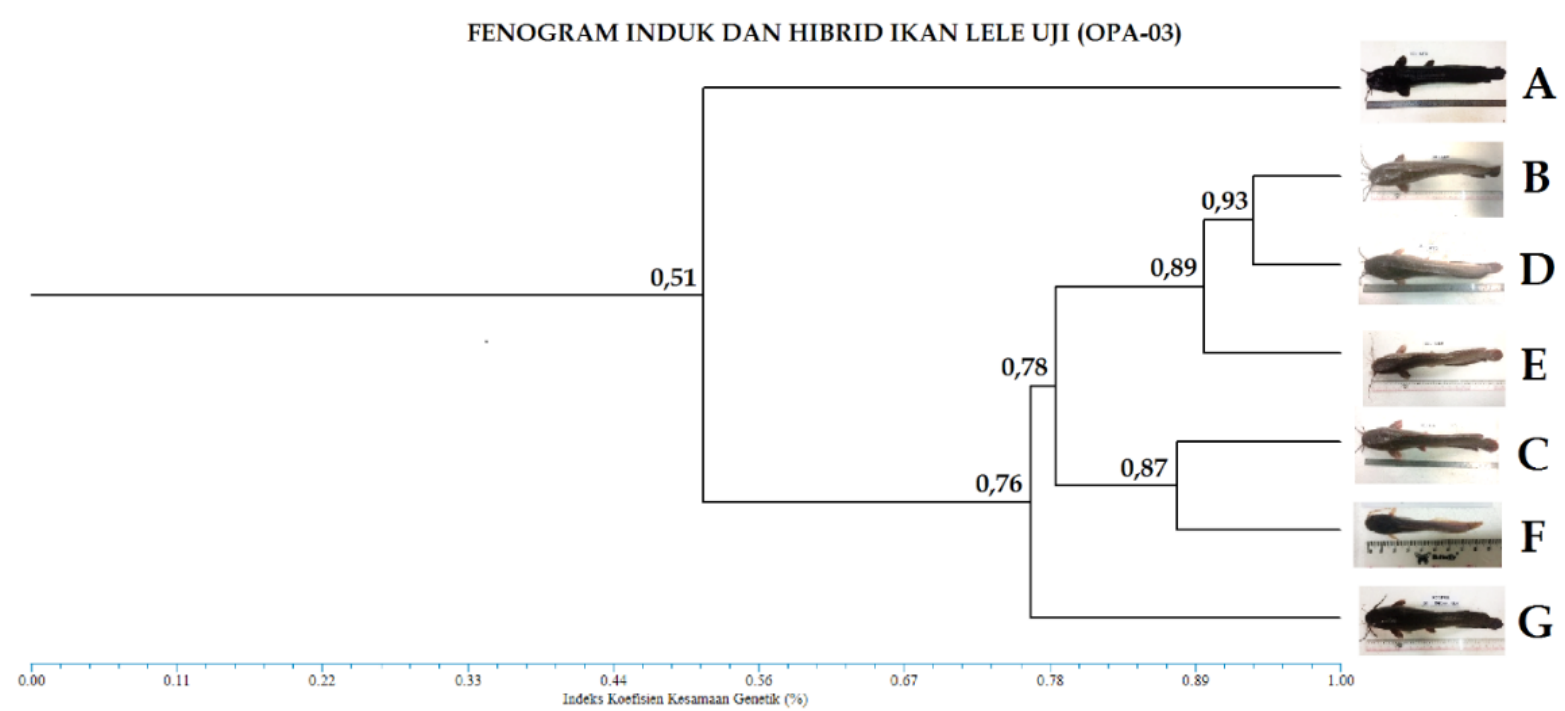

Figure 3. Fenogram Parent and Hybrid Catfish Test (OPA-03)

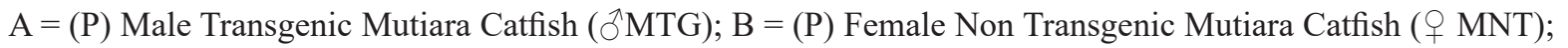

$\mathrm{C}=(\mathrm{P})$ Male Non Transgenic Mutiara Catfish $(\overbrace{}^{\wedge} \mathrm{MNT}) ; \mathrm{D}=(\mathrm{F} 1) \mathrm{MTG}><$ MNT Male Catfish; E $=(\mathrm{F} 1) \mathrm{MNT}$

$><$ MNT Female Catfish; F $=($ F2) MTG_MNT $><$ MNT_MNT Catfish; G = Sangkuriang Catfish (control)

\section{ACKNOWLEDGMENTS}

The authors delighted to thank the Head of the Hatchery Laboratory, Microbiology and Molecular Biotechnology Laboratory of Fisheries and Marine Science Universitas Padjadjaran to provide this work with the complete support.

Yolanisa et al.

\section{REFERENCES}

Adolfsson, A., Ackerman, M. \& Brownstein, N. C. (2018). To Cluster, or Not to Cluster: An Analysis of Clusterability Methods. Pattern Recognition.

Alimuddin, Yoshizaki, G., Carman, O. \& Sumantadinata, K. (2003). Aplication of 


\section{JURNAL BIDDJATI}

http://journal.uinsgd.ac.id/index.php/biodjati

Gene Transfer in Aquaculture. Jurnal Akuakultur Indonesia, 2(1), 41-50.

Arifin, O. Z., Cahyanti, W. \& Kristanto, H. (2017). Keragaman Genetik Tiga Generasi Ikan Tambakan (Helostoma temminkii) Dalam Program Domestikasi. Jurnal Riset Akuakultur, 12(4), 295-305.

Barbas, C. F., Burton, D. R., Scott, J. K. \& Silverman, G. J. (2007). Quantitation of DNA and RNA. Cold Spring Harbor Protocols, 2007(11).

Beheary, M. S., Almaaty, A. A. \& El-matary, F. (2015). Genetic Polymorphism and Changes in the Concentration of Heavy Metals in Catfish Clarias gariepinus from Different Sites as a Result of Environmental Contamination. Advances in Environmental Biology, 9(18), 20-32.

BPPI. (2014). Naskah Akademik Ikan Lele Tumbuh Cepat Hasil Seleksi Individu. Sukamandi.

Buwono, I. D., Iskandar, Agung, M. U. K. \& Subhan, U. (2016). Perakitan Ikan Lele (Clarias sp.) Transgenik dengan Teknik Elektroporasi Sperma. Jurnal Biologi, 20(1), 17-28.

Buwono, I. D., Lathifah, A. U. \& Subhan, U. (2018). Deteksi Keragaman Genotip Hibrid Ikan Lele Sangkuriang, Mutiara Transgenik dan Non Transgenik Pada Keturunan Pertama. Jurnal Biologi Indonesia, 14(1), 133-141.

Chattopadhyay, N.R.(2017). Negative Aspects of Breeding Practice. In Induced Fish Breeding. Elsevier Inc (pp. 105-134).

Cheng, S. S., Senoo, S., Siddiquee, S. \& Rodrigues, K. F. (2015). Genetic Variation in the Mitochondrial Genome of the Giant Grouper Epinephelus lanceolatus (Bloch, 1790) and its Application for the Identification of Broodstock. Aquaculture Reports, 2, 139-143.

Danish, M., Singh, I. J., Giri, P. \& Singh, C.
P. (2012). Molecular Characterization of Two Populations of Catfish Clarias batrachus L . Using Random Amplified Polymorphic DNA (RAPD) Markers. African Journal of Biotechnology, 11(77), 14217-14226.

Dewi, R. R. S. P. S., Marnis, H., Suprapto, R. \& Syawalia, N. (2013). Produksi Ikan Lele Cepat Tumbuh Generasi F0 Menggunakan Metode Transgenesis. Jurnal Riset Akuakultur, 8(2), 173-180.

Diani, A. F. (2013). Analisis Kekerabatan Strain Lele (Clarias Spp.) Menggunakan Penanda Genetik Berbasis RAPD$P C R$. Universitas Padjadjaran.

Dunham, R. A. (2004). Aquaculture and Fisheries Biotechnology Genetic Approaches. Wallingford, Oxfordshire: CABI Publishing.

El-Hawary, S. S., El-Tantawy, M. E., Kirollos, F. N. \& Hammam, W. E. (2018). Inter Simple Sequence Repeat (ISSR) and Start Codon Targeted Polymorphism (SCOT) as Discrimination Techniques Between Certain Apple and Pear Cultivars. International Research Journal of Pharmacy, 9(9).

FAO. (2001). Food and Agriculture Organization of the Unite Nations. GMOs and human health. Genetically modified organisms, consumer, food safety and the environment. Retrieved from http://www.fao.org/docrep/003/x9602e/ x9602e06.htm

Fatchiyah, Arumingtyas, E. L., Widyarti, S. \& Rahayu, S. (2011). Biologi Molekular: Prinsip Dasar Analisis. (R. Astikawati, $E d$.). Jakarta: Penerbit Erlangga.

Iswanto, B., Suprapto, R., Marnis, H. \& Imron. (2015). Karakteristik Morfologis Dan Genetis Ikan Lele Afrika (Clarias gariepinus Burchell, 1822) Strain $\mathrm{Mu}-$ tiara. Jurnal Riset Akuakultur, 10(3), 


\section{JURNAL BIDDJATI}

http://journal.uinsgd.ac.id/index.php/biodjati

325-334.

Khosravinia, H., Murthy, H. N. N., Parasad, D. T. \& Pirany, N. (2007). Optimizing Factors Influencing DNA Extraction from Fresh Whole Avian Blood. African Journal of Biotechnology, 6(4), 481-486.

Liu, Z. (2007). Chapter 3 Randomly Amplified Polymorphic. In Aquaculture Genome Technologies. Blackwell Publishing, pp. 21-28.

Liu, Z. J. \& Cordes, J. F. (2004). DNA Marker Technologies and Their Applications in Aquaculture Genetics. Aquaculture, 238, 1-37.

Liu, Z. J., Li, P., Argue, B. J. \& Dunham, R. A. (1999). Random Amplified Polymorphic DNA Markers: Usefulness For Gene Mapping and Analysis of Genetic Variation of Catfish. Aquaculture, 174, 59-68.

Mahaputro, G., Mishra, D., Shaw, K., Mishra, S. \& Jena, T. (2012). Phylogenetic Tree Construction for DNA Sequences using Clustering Methods. Procedia Engineering, 38, 1362-1366.

Muhammad, W. N. \& Andriyanto, S. (2013). Manajemen Budidaya Ikan Lele Dumbo (Clarias gariepinus) di Kampung Lele, Kabupaten Boyolali, Jawa Tengah. Media Akuakultur, 8(1), 63-72.

Muharam, E. G., Buwono, I. D. \& Mulyani, Y. (2012). Analisis Kekerabatan Ikan Mas Koi (Cyprinus carpio koi) dan Ikan Mas Majalaya (Cyprinus carpio carpio) Menggunakan Metode RAPD. Jurnal Perikanan Dan Kelautan, 3(3), 15-23.

Nei, M. \& Li, W.H. (1979). Mathematical Model for Studying Genetic Variation In Terms of Restriction Endonucleases. Proc. Natl. Acad. Sct. USA, 76(10), 5269-5273.
Permana, G. N., Moria, S. B., Hutapea, J. H. \& Haryanti. (2009). Profil Pemijahan Ikan Tuna Sirip Kuning, Thunnus albacares Dalam Bak Terkontrol Dengan Analisis Mitokondria DNA. Jurnal Riset Akuakultur, 4(2), 157-167.

Rasal, K. D., Chakrapani, V., Patra, S. K., Ninawe, A. S., Sundaray, J. K., Jayasankar, P. \& Barman, H. K. (2016). Status of Transgenic Fish Production With Emphasis on Development of Food Fishes and Novel Color Varieties of Ornamental Fish: Implication And Future Perspectives. Journal of Fisheries Sciences, 10(3), 52-65.

Sofro, A. S. M. (1994). Keanekaragaman Genetik (Edisi Pert). Yogyakarta: ANDI OFFSET.

Tenriulo, A., Suryati, E., Parenrengi, A. \& Rosmiat. (2001). Ekstraksi DNA Rumput Laut Kappaphycus alvarezii dengan Metode Fenol Kloroform. Marina Chimica Acta, 2(2), 6-10.

Williams, J. G. K., Kubelik, A. R., Livak, K. J., Rafalski, J. A. \& Tingey, S. V. (1990). DNA Polymorphisms Amplified By Arbitrary Primers Are Useful As Genetic Markers. Nucleic Acids Research, 18(22), 6531-6535.

Yousefian, M. \& Nejati, A. (2008). Inbreeding Depression by Family Matching in Rainbow Trout (Oncorhynchus mykiss). Journal of Fisheries and Aquatic Science, 3(6), 384-391.

Zulfahmi, Z. (2013). Penanda DNA Untuk Analisis Genetik Tanaman. Jurnal Agroteknologi, 3(2), 41-52. 